\title{
Rearing of Lymnaea columella (Say, 1817), Intermediate Host of Fasciola hepatica (Linnaeus, 1758)
}

\author{
Cecília Pereira de Souza ${ }^{+}$, Kelly Grace Magalhães ${ }^{++}$
}

Laboratório de Malacologia, Centro de Pesquisas René Rachou-Fiocruz, Av. Augusto de Lima 1715, 30190-002

Belo Horizonte, MG, Brasil

The intermediate host of Fasciola hepatica, Lymnaea columella, collected in Belo Horizonte, Minas Gerais, Brazil, was reared in our laboratory. The aim of the current study was to standardize a rearing and maintenance technique. Two kinds of diet were tested: fresh lettuce $(A)$ and rodent ration $+10 \%$ $\mathrm{CaCO}_{3}$ plus fresh lettuce $(B)$. The age for the beginning of oviposition ranged from 27 to 57 days. Ten days after oviposition at $24.7^{\circ} \mathrm{C}, 100 \%$ eclosion occurred. The complete life cycle varied from 37 to 67 days. The average numbers of eggs per egg mass were 26.3 and 31.1 with diets $(A)$ and $(B)$, respectively. The lettuce and ration fed snails presented a increased growth although the difference was not statistically significant $(p>0.05)$. The mortality rate varied from 40 to $64 \%$ after 90 days. The maximum longevity was 183 days, $21.5 \mathrm{~mm}$ length and $11 \mathrm{~mm}$ wide. The methodology to mass breed and maintain these snails was found to be suitable in the laboratory

Key words: fasciolosis - Lymnaea columella - intermediate host - Minas Gerais - Brazil - rearing techniques

The geographic distribution of Lymnaeidae is very wide in Brazil (Paraense 1982a,b, 1983, 1986). In Minas Gerais, Lymnaea columella specimens from Sete Lagoas, Santa Rita do Sapucaí, Viçosa and Belo Horizonte municipalities were found to be susceptible to experimental infection with Fasciola hepatica miracidia (Dacal et al. 1988). Recently, Silva et al. (1995) reported the first natural infection of $L$. columella with $F$. hepatica in Itajubá, southern of Minas Gerais. In a malacology survey performed in 13 municipalities in the Belo Horizonte microregion, L. columella was found in eight: Pedro Leopoldo, Lagoa Santa, Santa Luzia, Vespasiano, Ribeirão das Neves, Belo Horizonte, Nova Lima and Betim (Souza et al. 1998).

This study initiated the rearing of $L$. columella, collected in Belo Horizonte. The aims of the study were to standardize a breeding and maintenance technique for these snails collecting data on growth, oviposition, number of eggs per egg mass, egg incubation period and longevity. In the future, these snails will be submitted to experimental infection with $F$. hepatica in order to obtain the eggs, cercariae, metacercariae and the adult worms to study vaccine production.

\footnotetext{
${ }^{+}$Corresponding author. Fax:+55-31-295.3115. E-mail: souzacp@ netra.fiocruz.br ${ }^{++}$Research fellow CNPq Received 18 August 1999 Accepted 9 February 2000
}

\section{MATERIALS AND METHODS}

Snails used in this study were collected from a breeding colony at Pontifícia Universidade Católica campus in Belo Horizonte, MG, in March 1998. After identification by Dr WL Paraense from the Malacology Department of Instituto Oswaldo Cruz, Rio de Janeiro the snails were divided in two groups of 25 and placed in two $60 \times 30 \times 28 \mathrm{~cm}$ glass aquaria. Each aquarium containing approximately 101 of dechlorinated water was provided with a water stream during $8 \mathrm{~h}$ per day. As substrate, sterilized soil $+10 \%$ calcium carbonate $\left(\mathrm{CaCO}_{3}\right)$ was added to the water. The aquaria were maintained on metal shelves with natural light exposure. Two samples of water containing algae and the aquatic plant (Lemna sp.) were added to the aquaria. The water temperature and $\mathrm{pH}$ were monitored daily. To collect the eggs, uncolored plastic sheets were put into the two aquaria (Olivier 1960). To control predators such as oligochaetes worms and ostracods, which could have come from the field with the snails, acetic acid was used to wash the contaminated aquaria.

Experiments - Two experiments testing two diets were performed. The snails in aquarium A were fed fresh lettuce and in $\mathrm{B}$, fresh lettuce plus rodent powered ration $\left(\right.$ Purina $\left.{ }^{\circledR}\right)+10 \% \mathrm{CaCO}_{3}$; the latter diet has already been used to feed Biomphalaria in our laboratory (Souza et al. 1985, 1987). The paste ration was placed on the lettuce leaves. In the first experiment, 100 newly hatched snails were used, 50 in each aquarium. In experiment two, 343 specimens were used in A aquarium and 401 in B. 
Snail development was evaluated by measurement and counting after 30, 60, 90, 120 and 150 days post eclosion. Any dead specimens were removed. To observe longevity in the laboratory, in experiment two, 20 specimens which were 60 days old, from each aquarium were marked with enamel.

Statistical analysis: the average reared snail lengths were compared using Student $t$ test $(\mathrm{p} \geq 0.05)$.

\section{RESULTS}

Egg eclosion occurred 10 days after oviposition, at $24.7^{\circ} \mathrm{C}$ and the eclosion rate was $100 \%$ in both experiments. The age for the first oviposition ranged from 27 days in the first experiment and 57 days in the second experiment. The complete life cycle ranged from 37 to 67 days. The average egg snails per egg mass was 26.3 and 31.1 for aquaria $\mathrm{A}$ and $\mathrm{B}$, respectively.
Data on snails growth and mortality in the two experiments, and the average water temperatures are shown in Tables I and II. The snails which were fed with lettuce plus ration developed faster than those in the other group, although the difference was not statistically significant ( $p>0.05$ ). After 90 days 60 to $64 \%$ of mortality was observed among the snails of the first experiment and 40.89 to $41.69 \%$ among the snails of the second experiment (Tables I, II). Water $\mathrm{pH}$ varied from 6.7 to 6.9 and the temperature from 24.7 to $27.6^{\circ} \mathrm{C}$.

From March 1998 to March 1999 approximately eight $L$. columella generations and 3,000 additional specimens were obtained in six aquaria in our laboratory. During the hottest months, December 1998, January and February 1999, the mortality of adult snails was higher.

TABLE I

Growth and mortality of Lymnaea columella reared in the laboratory, fed with lettuce (A) and lettuce plus rodent ration $+10 \% \mathrm{CaCO}_{3}(\mathrm{~B})$, in the experiment 1

\begin{tabular}{ccccccc}
\hline Aquaria & $\begin{array}{c}\text { Number } \\
\text { of snails }\end{array}$ & $\begin{array}{c}\text { Age } \\
(\text { day })\end{array}$ & $\begin{array}{c}\text { Average } \\
\text { length }(\mathrm{mm})\end{array}$ & $\begin{array}{c}\text { Average } \\
\text { width }(\mathrm{mm})\end{array}$ & $\begin{array}{c}\text { Mortality } \\
\text { rate }(\%)\end{array}$ & $\begin{array}{c}\text { Average } \\
\text { temperature }\left({ }^{\circ} \mathrm{C}\right)\end{array}$ \\
\hline $\mathrm{A}$ & 50 & 1 & 1.11 & 0.68 & 0.0 & 25.1 \\
$\mathrm{~B}$ & 50 & 1 & 1.11 & 0.68 & 0.0 & 25.2 \\
$\mathrm{~A}$ & 50 & 30 & 4.78 & 2.21 & 0.0 & 25.1 \\
$\mathrm{~B}$ & 50 & 30 & 4.64 & 2.30 & 0.0 & 25.2 \\
$\mathrm{~A}$ & 41 & 60 & 14.21 & 7.09 & 18.0 & 24.7 \\
$\mathrm{~B}$ & 48 & 60 & 15.39 & 7.60 & 4.0 & 24.7 \\
$\mathrm{~A}$ & 18 & 90 & 18.17 & 8.55 & 64.0 & 25.3 \\
B & 20 & 90 & 19.62 & 9.04 & 60.0 & 25.4 \\
\hline
\end{tabular}

The beginning of the eggs output occurred at 27 days after eclosion.

TABLE II

Growth and mortality of Lymnaea columella reared in the laboratory, fed with lettuce (A) and lettuce plus rodent ration $+10 \% \mathrm{CaCO}_{3}(\mathrm{~B})$, in the experiment 2

\begin{tabular}{lcccccc}
\hline Aquaria & $\begin{array}{c}\text { Number } \\
\text { of snails }\end{array}$ & $\begin{array}{c}\text { Age } \\
\text { (day) }\end{array}$ & $\begin{array}{c}\text { Average } \\
\text { length }(\mathrm{mm})\end{array}$ & $\begin{array}{c}\text { Average } \\
\text { width }(\mathrm{mm})\end{array}$ & $\begin{array}{c}\text { Mortality } \\
\text { rate }(\%)\end{array}$ & $\begin{array}{c}\text { Average } \\
\text { temperature }\left({ }^{\circ} \mathrm{C}\right)\end{array}$ \\
\hline A & 343 & 1 & 1.11 & 0.68 & 0.0 & 24.7 \\
B & 401 & 1 & 1.11 & 0.68 & 0.0 & 24.7 \\
A & 343 & 30 & 2.41 & 1.16 & 0.0 & 24.7 \\
B & 401 & 30 & 3.03 & 1.44 & 0.0 & 24.7 \\
A & 335 & 60 & 6.85 & 3.45 & 2.33 & 27.6 \\
B & 395 & 60 & 7.59 & 3.87 & 1.49 & 27.4 \\
A & 200 & 90 & 12.21 & 5.37 & 41.69 & 25.0 \\
B & 237 & 90 & 14.42 & 7.84 & 40.89 & 25.1 \\
A & 147 & 120 & 14.71 & 7.63 & 57.14 & 26.1 \\
B & 152 & 120 & 18.25 & 8.76 & 62.09 & 26.0 \\
A & 32 & 150 & 17.01 & 8.62 & 90.6 & 25.0 \\
B & 102 & 150 & 18.50 & 9.62 & 74.5 & 24.9 \\
\hline
\end{tabular}

The beginning of the eggs output occurred at 57 days after eclosion. 
The greatest $L$. columella longevity period recorded in these experiments was 183 days. The length was $21.5 \mathrm{~mm}$ and the width $11 \mathrm{~mm}$.

\section{DISCUSSION}

Several authors have developed Lymnaea snail rearing techniques in the laboratory (Noland \& Reichel 1943, Madsen \& Monrad 1981, Sanchez et al. 1995). However, these techniques are highly variable and special techniques must be used when rearing species such as Fossaria cubensis and $L$. columella, the F. hepatica hosts in Cuba and Brazil, respectively, which are amphibious snails.

Snail rearing techniques, maintenance of the aquaria and diet are extremely variable. Preferentially, small recipients including Petri dish and crystallizing recipients are used. Large water tanks are also used, mainly to grow algae to feed the snails.

In the present study, the methodology used to rear L. columella in the laboratory was the same as that used for B. glabrata mass growing (Souza et al. 1985, 1987), with satisfactory results (Tables I, II). Initially, in addition to lettuce and powered ration, algae and the aquatic plant (Lemna sp.) were introduced into the aquaria, but because of the great voracity of the snails the feeding was simplified to just lettuce and lettuce plus ration, $+10 \% \mathrm{CaCO}_{3}$.

The effects of snail crowding in population were observed in one of the experiments as reported by Gazzinelli et al. (1970), in B. glabrata. In the former, the 50 snails developed faster than those in the latter experiment in which 343 and 401 specimens were growing together (Tables I, II).

The age of the snails for the first oviposition varied from 27 to 57 days, being higher than that reported for $F$. cubensis which ranged from 18 to 20 days after eclosion (Sanchez et al. 1995). The snail mortality rates ranged from 40 to $64 \%$ at 90 days old (Tables I, II) indicating that infections with $F$. hepatica should be performed at around 30 days old (2-5 mm length). The largest size registered after 183 days for L. columella, from Belo Horizonte, and reared in our laboratory was $21.5 \mathrm{~mm}$ in length and $11 \mathrm{~mm}$ in width; these measurements exceed those reported for specimens from different regions of the country (Paraense 1983, 1986).

The methodology used to rear and maintain these snails was found to be suitable in the laboratory. The preferred diet to rear Lymnaea is lettuce plus powered ration $+10 \% \mathrm{CaCO}_{3}$ the same as for Biomphalaria.

\section{ACKNOWLEDGEMENTS}

To Professor Roney Elias da Silva from the Departamento de Parasitologia, Universidade Federal de Minas Gerais, for collecting and providing the snails. To
Dr Wladimir Lobato Paraense from the Departamento de Malacologia, Instituto Oswaldo Cruz, Rio de Janeiro, for the specific identification of the snails. To Dr Neusa Araújo from the Laboratório de Esquistossomose, Centro de Pesquisas René Rachou, for the statistical analysis.

\section{REFERENCES}

Dacal ARC, Costa HMA, Leite ACR 1988. Susceptibilidade de Lymnaea (Pseudosuccinea) columella (Say, 1817) exposta à infecção por miracídios de Fasciola hepatica (Linnaeus, 1758). Rev Inst Med Trop S Paulo 30: 361-369.

Gazzinelli GF, Ramalho-Pinto J, Pellegrino J, Gilbert B 1970. Uptake of ${ }^{59} \mathrm{Fe}$ as a tool for study of the crowding effect in Biomphalaria glabrata. Am J Trop Med Hyg 19: 1034-1037.

Madsen H, Monrad J 1981. A method for laboratory maintenance of Lymnaea natalensis and for mass production of Fasciola gigantica metacercariae. $J$ Parasitol 67: 735-737.

Noland LE, Reichel E 1943. Life cycle of Lymnaea stagnalis completed at room temperature without access to air. Nautilus 57: 8-13.

Olivier L 1960. The employment of snail eggs for chemical tests. Working paper. WHO/Bilharziasis no. 145.

Paraense WL 1982a. Lymnaea viatrix and L. columella in the Neotropical region: a distributional outline. Mem Inst Oswaldo Cruz 77: 181-188.

Paraense WL 1982b. Lymnaea rupestris sp. n. from southern Brazil (Pulmonata-Lymnaeidae). Mem Inst Oswaldo Cruz 77: 437-443.

Paraense WL 1983. Lymnaea columella in Northern Brazil. Mem Inst Oswaldo Cruz 78: 477-482.

Paraense WL 1986. Lymnaea columella: two new Brazilian localities in the states of Amazonas and Bahia. Mem Inst Oswaldo Cruz 81: 121-123.

Sanchez RS, Perera G, Sanchez J 1995. Cultivo de Fossaria cubensis (Pfeiffer) (Pulmonata: Lymnaeidae) hospedero intermediario de Fasciola hepatica en Cuba. Rev Cubana Med Trop 47: 71-73.

Silva RE, Lima WS, Caldas WS, Cury MC, Malacco AF 1995. Primeiro encontro de Lymnaea columella (Say, 1817) naturalmente infectada por estádios intermediários de Fasciola hepatica (Linnaeus, 1758) na cidade de Itajubá, MG. In XIV Congresso Brasileiro de Parasitologia, Goiás, p. 205.

Souza CP, Araújo N, Jannotti LK, Gazzinelli G 1987. Fatores que podem afetar a criação e a manutenção de caramujos infectados e a produção de cercárias de Schistosoma mansoni. Mem Inst Oswaldo Cruz 82: 73-79.

Souza CP, Gazzinelli G, Araújo N, Rosa-Cruz O, Silva CRT 1985. Criação de caramujos infectados para obtenção em massa de cercárias e esquistossômulos. Mem Inst Oswaldo Cruz 80: 55-61.

Souza CP, Lima LC, Jannotti-Passos LK, Ferreira SS, Guimarães CT, Vieira IBF, Mariani-Junior R 1998. Moluscos límnicos da microrregião de Belo Horizonte, MG, com ênfase nos vetores de parasitoses. Rev Soc Bras Med Trop 31: 449-456. 